\title{
HARD ROCK EXCAVATION FOR FOUNDATIONS: MYTHS AND BEST PRACTICES IN ROCK BLASTING
}

\author{
Srikant Vairagare ${ }^{1}$, G. Shivaleelanand ${ }^{2}$ \\ ${ }^{I}$ Managing Director, Uttam Blastech Pvt Ltd, Hyderabad \\ ${ }^{2}$ Architect, Matrix Consultants, Hyderabad
}

\begin{abstract}
Each high-rise building requires equally deep foundations. Part of India that is expanding fast such as South and West India are sitting on one of the hardest rock known to the mankind such as Granites and Basalts. Thus, leaving no other option but to resort to Rock Blasting for excavation of foundations.

Green building guidelines suggest least disturbance to the expense of natural ground for cellars. It indirectly suggests buildings to limit their basements to building outer line only not going beyond building line into setback areas, which necessitates going for deeper excavations. Provision of mechanical parking in basements necessitates more heights in basements, hence deeper excavations.

Blasting creates nuisances such as Fly Rock (Flying projectiles), Noise, Heat, Vibrations and Noxious Fumes. Blasting damage is often falsely compared to damage resulting from earth quake. Mishandling of situation had resulted in abandoning construction of a few floors and enormous delay in project execution. There are instances of few projects being stopped altogether.

Controlled blasting limits the spread of dust, sound and limits the flying fragments making the construction process green. Blasting is the cheapest and the fastest method of Rock Breakage. It's the safest too, as can be seen its use in crowded cities such as Hong Kong for the construction of Hong Kong Metro, where up to and 1100 Cubic Meters of Hard Rock was excavated per day and the city of New York for reconstruction near World Trade Centre, where slightest error would not only stop the project but would attract penalties to the tune of millions of USD.

This paper discusses the ways to dispel the fears about blasting and use it effectively in Indian Civil Engineering practices.
\end{abstract}

\section{INTRODUCTION TO ROCK BLASTING}

Rock breaking and excavation are as old as civilisation. Material excavation, handling and transportation are essential components of Mining and Civil Engineering. Every handling involves breaking of rock; if it's hard, by using some or other forms of energy, be it Mechanical or chemical.

\section{IMPORTANCE OF ROCK BLASTING}

With increased emphasis on infrastructure, size and complexities of excavations in civil engineering practices have gone up as can be seen in the table below.

TABLE-I : Changes In Excavation Requirements For Building Construction

\begin{tabular}{|c|c|c|}
\hline & Before 15 Years & Today \\
\hline $\begin{array}{l}\text { Average } \\
\text { Height } \\
\text { Building }\end{array}$ & $9-15 \mathrm{~m}$ & $45-90 \mathrm{~m}$ \\
\hline $\begin{array}{l}\text { Average } \\
\text { Depth of } \\
\text { Excavation }\end{array}$ & $1-2 m$ & $8-10 \mathrm{~m}$ \\
\hline $\begin{array}{l}\text { Concrete } \\
\text { Consumption } \\
\text { in a Building }\end{array}$ & $\begin{array}{l}0.8-0.9 \mathrm{cft} / \mathrm{sft} \text { of } \\
\text { slab area }\end{array}$ & $\begin{array}{l}2-3 \mathrm{cft} / \mathrm{sft} \text { of } \mathrm{slab} \\
\text { area }\end{array}$ \\
\hline $\begin{array}{l}\text { Method of } \\
\text { Rock Breaking }\end{array}$ & Mostly Manual & $\begin{array}{l}\text { Always by } \\
\text { Mechanical Means }\end{array}$ \\
\hline
\end{tabular}

Among the latest developments of this arena, material handling practices are basically faster, safer, and easier material handling processes. Every material handling process consists of Breaking, Loading, Hauling, and Disposal. In that order, Rock Breaking is the first process of Material Handling and is the first process of all Civil and Mining Engineering Practices. Among all the Rock Breaking methods, use of chemical energy for Rock Breaking is the cheapest and the fastest method as can be seen from below sketch.

\section{BLASTING ALTERNATES}

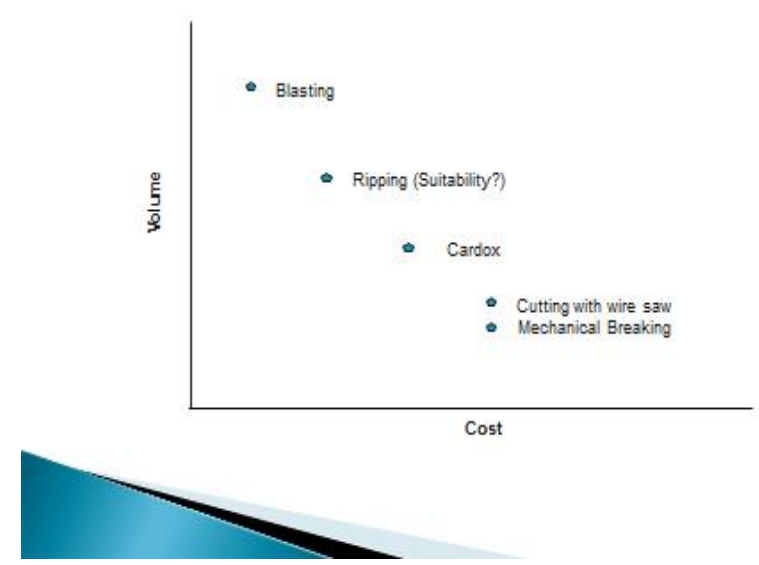




\section{CHANGING SCENARIO}

Now the Reality that every Civil and Mining Engineer dealing with Excavation faces are:

1. Demands for higher quantities in shorter durations.

2. Increasing awareness amongst neighbours and stake holders

3. Increasing cost of delays.

4. Need for compliances.
5. Being legally right and documenting so to insulate against any future claims.

The problem is not unique to India but is more pronounced in advance countries where compliance requirements and public glare are much higher.

There are no alternatives to use of explosives, even in countries with lot of restrictions on use of explosives and high cost of legal compliances; explosives are increasingly used for Rock Breaking.

INTERNATIONAL EXAMPLES

Blasting in progress in a crowded area of Hong Kong

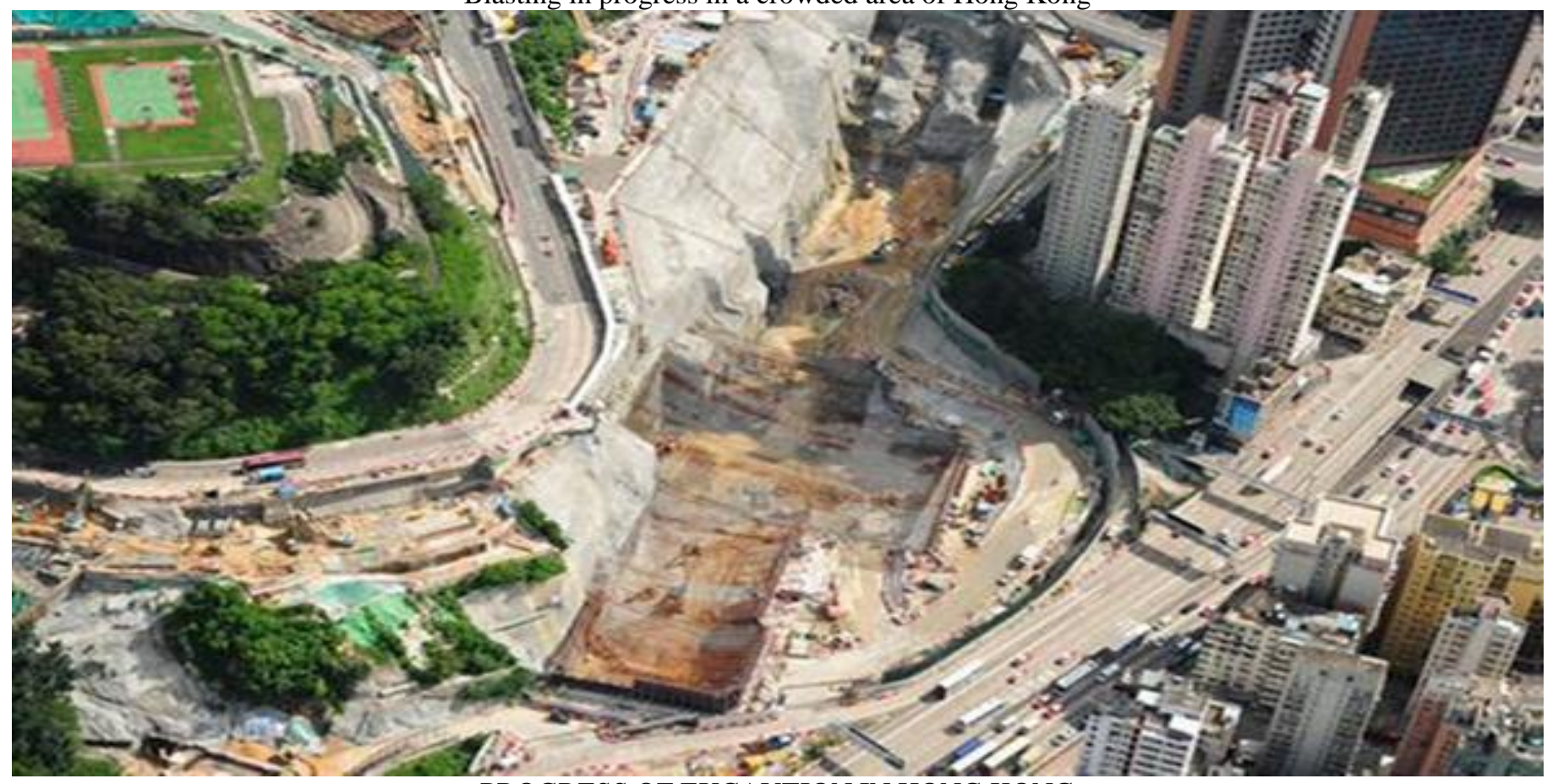

PROGRESS OF EXCAVTION IN HONG KONG

BLAST WISE OUTPUT IN HONGKONG

\begin{tabular}{|c|c|c|c|c|c|c|c|c|c|c|c|c|c|c|c|c|}
\hline 2012 & $\begin{array}{l}\text { TOT } \\
\text { AL } \\
\text { VOL } \\
\text { UME }\end{array}$ & 1 & & 2 & 3 & 4 & & 5 & 6 & 7 & 8 & 9 & & & $\begin{array}{l}1 \\
4\end{array}$ & $\begin{array}{l}1 \\
5\end{array}$ \\
\hline June & 651 & 245 & & $\begin{array}{l}2 \\
0 \\
3\end{array}$ & $\begin{array}{l}20 \\
3\end{array}$ & & & & & & & & & & & \\
\hline July & 203 & 203 & & & & & & & & & & & & & & \\
\hline$\overline{\text { Aug }}$ & 1088 & 375 & & $\begin{array}{l}3 \\
4 \\
1\end{array}$ & $\begin{array}{l}37 \\
2\end{array}$ & & & & & & & & & & & \\
\hline Sept & 1379 & 216 & & $\begin{array}{l}3 \\
7 \\
2 \\
\end{array}$ & $\begin{array}{l}37 \\
2\end{array}$ & 210 & & 1 & & & & & & & & \\
\hline Oct & 3045 & 372 & & $\begin{array}{l}3 \\
7 \\
2\end{array}$ & $\begin{array}{l}21 \\
0\end{array}$ & 372 & & 3 & $\begin{array}{l}37 \\
2\end{array}$ & $\begin{array}{l}37 \\
2\end{array}$ & $\begin{array}{l}37 \\
2\end{array}$ & $\begin{array}{l}3 \\
2\end{array}$ & & & & \\
\hline Nov & 2222 & $\begin{array}{r}372 \\
3 \\
7 \\
\end{array}$ & $\begin{array}{l}3 \\
7\end{array}$ & $\begin{array}{l}3 \\
3 \\
8\end{array}$ & $\begin{array}{l}27 \\
8\end{array}$ & $\begin{array}{l}333 \\
39\end{array}$ & $\begin{array}{l}3 \\
3 \\
9 \\
\end{array}$ & 7 & $\begin{array}{l}27 \\
8\end{array}$ & $\begin{array}{l}33 \\
9\end{array}$ & & & & & & \\
\hline
\end{tabular}

Volume: 05 Special Issue: 20 | ACCE : REDECON-2016| Nov-2016, Available @ https://www.esatjournals.org 287 


\begin{tabular}{|c|c|c|c|c|c|c|c|c|c|c|c|c|c|c|c|c|c|c|c|}
\hline & & & 2 & 2 & & & & & & & & & & & & & & & \\
\hline Dec & & 1724 & 278 & & $\begin{array}{l}3 \\
6 \\
5\end{array}$ & $\begin{array}{l}37 \\
2\end{array}$ & 338 & $\begin{array}{l}3 \\
7 \\
2\end{array}$ & & & & & & & & & & & \\
\hline Jan & & 2082 & 372 & & $\begin{array}{l}3 \\
7 \\
2\end{array}$ & $\begin{array}{l}44 \\
6\end{array}$ & 446 & $\begin{array}{l}4 \\
4 \\
6\end{array}$ & & & & & & & & & & & \\
\hline Feb & & 1822 & 372 & & $\begin{array}{l}3 \\
7 \\
2\end{array}$ & $\begin{array}{l}37 \\
2\end{array}$ & 372 & $\begin{array}{l}3 \\
3 \\
5\end{array}$ & & & & & & & & & & & \\
\hline March & & 372 & 372 & & & & & & & & & & & & & & & & \\
\hline Total & & 14588 & & & & & & & & & & & & & & & & & \\
\hline \begin{tabular}{l|}
20 \\
13
\end{tabular} & $\begin{array}{l}\text { EIS } \\
\mathrm{m} 3 / \mathrm{m} \\
\text { onth }\end{array}$ & & & & & & & & & & & & & & & & & & \\
\hline March & & 2737 & 339 & & $\begin{array}{l}3 \\
3 \\
9\end{array}$ & $\begin{array}{l}34 \\
5\end{array}$ & 355 & $\begin{array}{l}4 \\
0 \\
6\end{array}$ & $\begin{array}{l}60 \\
8\end{array}$ & & & & & & & & & & \\
\hline April & & 7444 & 521 & & $\begin{array}{l}5 \\
9 \\
5\end{array}$ & $\begin{array}{l}80 \\
4\end{array}$ & 434 & $\begin{array}{l}7 \\
4 \\
1\end{array}$ & $\begin{array}{l}56 \\
4\end{array}$ & $\begin{array}{l}40 \\
8\end{array}$ & $\begin{array}{l}3 \\
7\end{array}$ & & $\begin{array}{l}65 \\
1\end{array}$ & $\begin{array}{l}3 \\
3 \\
3\end{array}$ & $\begin{array}{l}51 \\
5\end{array}$ & $\begin{array}{l}4 \\
8 \\
8\end{array}$ & & & \\
\hline May & & 7401 & 409 & & $\begin{array}{l}4 \\
4 \\
9\end{array}$ & $\begin{array}{l}16 \\
4\end{array}$ & 389 & $\begin{array}{l}2 \\
7 \\
1\end{array}$ & $\begin{array}{l}78 \\
7\end{array}$ & $\begin{array}{l}57 \\
5\end{array}$ & $\begin{array}{l}5 \\
3\end{array}$ & & $\begin{array}{l}48 \\
4\end{array}$ & $\begin{array}{l}4 \\
1 \\
5\end{array}$ & $\begin{array}{l}40 \\
9\end{array}$ & $\begin{array}{l}5 \\
6 \\
6\end{array}$ & $\begin{array}{l}2 \\
1 \\
7\end{array}$ & $\begin{array}{l}4 \\
4 \\
6\end{array}$ & $\begin{array}{l}4 \\
8 \\
7\end{array}$ \\
\hline June & & 9365 & 507 & & $\begin{array}{l}2 \\
2 \\
7\end{array}$ & $\begin{array}{l}56 \\
3\end{array}$ & 636 & $\begin{array}{l}9 \\
3 \\
0\end{array}$ & $\begin{array}{l}80 \\
3\end{array}$ & $\begin{array}{l}37 \\
0\end{array}$ & $\begin{array}{l}90 \\
2\end{array}$ & & $\begin{array}{l}98 \\
2\end{array}$ & $\begin{array}{l}2 \\
6 \\
8\end{array}$ & $\begin{array}{l}52 \\
0\end{array}$ & $\begin{array}{l}9 \\
7 \\
1\end{array}$ & & & \\
\hline July & & 9418 & 862 & & $\begin{array}{l}6 \\
9 \\
2 \\
\end{array}$ & $\begin{array}{l}57 \\
8\end{array}$ & 905 & $\begin{array}{l}9 \\
2 \\
4 \\
\end{array}$ & $\begin{array}{l}57 \\
2\end{array}$ & $\begin{array}{l}74 \\
1\end{array}$ & $\begin{array}{l}7( \\
2\end{array}$ & & $\begin{array}{l}73 \\
0\end{array}$ & $\begin{array}{l}4 \\
1 \\
6\end{array}$ & $\begin{array}{l}10 \\
46\end{array}$ & & & & \\
\hline Augus & & 6606 & 469 & & $\begin{array}{l}7 \\
8 \\
9\end{array}$ & $\begin{array}{l}54 \\
1\end{array}$ & 654 & $\begin{array}{l}4 \\
6 \\
1\end{array}$ & $\begin{array}{l}49 \\
5\end{array}$ & $\begin{array}{l}49 \\
1\end{array}$ & $\begin{array}{l}28 \\
3\end{array}$ & & $\begin{array}{l}43 \\
6\end{array}$ & $\begin{array}{l}7 \\
6 \\
6\end{array}$ & & & & & \\
\hline Sept & & 9114 & 559 & & $\begin{array}{l}8 \\
0 \\
5\end{array}$ & $\begin{array}{l}48 \\
6\end{array}$ & 781 & $\begin{array}{l}9 \\
5 \\
3\end{array}$ & $\begin{array}{l}92 \\
4\end{array}$ & $\begin{array}{l}18 \\
6\end{array}$ & $\begin{array}{l}68 \\
6\end{array}$ & & $\begin{array}{l}95 \\
2\end{array}$ & $\begin{array}{l}7 \\
3 \\
9\end{array}$ & & & & & \\
\hline Oct & & 8464 & 632 & & $\begin{array}{l}6 \\
8 \\
6 \\
\end{array}$ & $\begin{array}{l}76 \\
6\end{array}$ & 405 & $\begin{array}{l}8 \\
2 \\
7 \\
\end{array}$ & $\begin{array}{l}67 \\
2\end{array}$ & $\begin{array}{l}85 \\
1\end{array}$ & $\begin{array}{l}72 \\
9\end{array}$ & & $\begin{array}{l}10 \\
45\end{array}$ & $\begin{array}{l}3 \\
7 \\
4 \\
\end{array}$ & & & & & \\
\hline Nov & & 12000 & 1059 & & $\begin{array}{l}9 \\
3 \\
8\end{array}$ & $\begin{array}{l}48 \\
9\end{array}$ & 562 & $\begin{array}{l}5 \\
8 \\
0\end{array}$ & $\begin{array}{l}14 \\
30\end{array}$ & $\begin{array}{l}14 \\
13\end{array}$ & $\begin{array}{l}17 \\
2 .\end{array}$ & & $\begin{array}{l}14 \\
76\end{array}$ & & & & & & \\
\hline Dec & & 4252 & 1625 & & $\begin{array}{l}6 \\
6 \\
4\end{array}$ & $\begin{array}{l}10 \\
36\end{array}$ & 601 & & & & & & & & & & & & \\
\hline Total & & 76801 & & & & & & & & & & & & & & & & & \\
\hline
\end{tabular}

Blasting in New York for construction of twin towers where World Trade centre Existed 


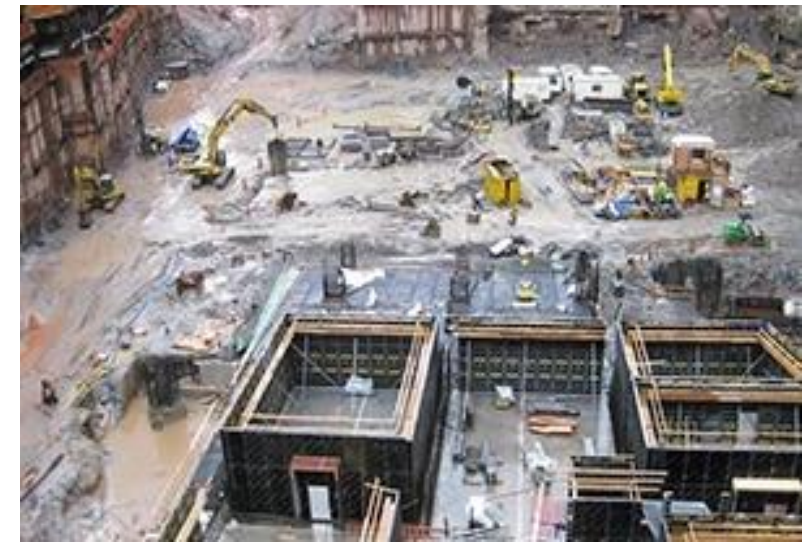

USE OF EXPLOSIVES RESULTS IN:

1. Ground Vibrations

2. Sound

3. Dust

\section{NITROUS FUMES}

While gases and heat are not a major concern as they dissipate in the atmosphere without causing much harm or apprehension to the neighbours; it's the ground vibrations' and sound, more appropriately air, overhead pressure that has the potential to damage structures, and cause apprehension among the neighbours.

Following tables shows permissible Vibration Limits sound generated in daily activities.

\section{DAMAGE LIMITS:}

Permissible Peak Particle Velocity (PPV) at the foundation level of structures in the mining areas in $\mathrm{mm} / \mathrm{sec}$

Table - 5

\begin{tabular}{|l|l|l|l|l|}
\hline $\begin{array}{l}\text { TYPE } \\
\text { STRUCTURES }\end{array}$ & OF & \multicolumn{2}{l|}{ DOMINANT } \\
EXCITATION \\
FREQUENCY \\
\hline
\end{tabular}

A) Buildings / structures not belonging to the owner.

\begin{tabular}{|c|c|c|c|}
\hline $\begin{array}{l}\text { Domestic } \quad \text { Houses } \\
\text { /Structures } \\
\text { (Kacha, Brick and } \\
\text { Cement). }\end{array}$ & 5 & 10 & 15 \\
\hline $\begin{array}{l}\text { Industrial buildings } \\
\text { (RCC and Framed } \\
\text { Structure). }\end{array}$ & 10 & 20 & 25 \\
\hline $\begin{array}{l}\text { Objects of Historical } \\
\text { Importance and } \\
\text { Sensitive structures. }\end{array}$ & 2 & 5 & 10 \\
\hline
\end{tabular}

B) Buildings belonging to the owner with limited span of life.

\begin{tabular}{|l|l|l|l|}
\hline $\begin{array}{l}\text { Domestic Houses } \\
\text { /Structures }\end{array}$ & $\mathbf{1 0}$ & $\mathbf{1 5}$ & $\mathbf{2 0}$ \\
$\begin{array}{l}\text { Kacha, Brick and } \\
\text { Cement). }\end{array}$ & & & \\
\hline $\begin{array}{l}\text { Industrial buildings } \\
\text { (RCC and Framed }\end{array}$ & $\mathbf{1 5}$ & $\mathbf{2 5}$ & $\mathbf{5 0}$ \\
\hline
\end{tabular}

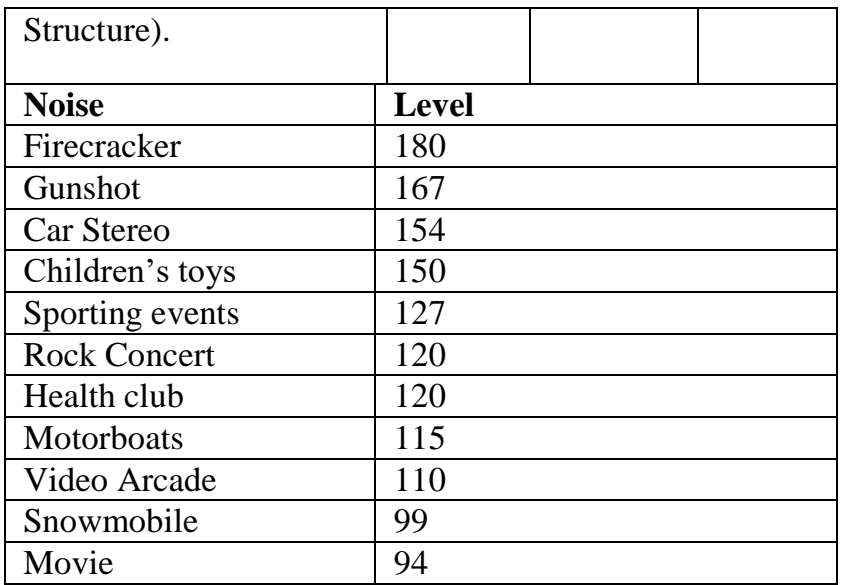

\section{LEGAL POSITION}

In number of cases, the matters got escalated to courts, promoters unable to tackle the complaints have redesigned their projects reducing rock excavations or opting for much slower alternatives such as Rope Cutting or Expansive agents.

Some of the examples are:

1. Suspension of RockBlasting for 3 months in construction ofKannur Airport.

2. Judgmentof Honourable High Court of Andhra Pradesh in case Zafar Javed,V/s State of Andhra Pradeshsuspending the work.

\section{MYTHS}

Some myths that we come across every day are,

1. Blasting is absolutely dangerous.

2. Its unwanted effects are not controllable.

3. Only way to Safe Blasting is use lesser explosives.

4. Higher the weight of covering material the better it is.

5. Rock Blasting Slows down the project schedule.

When compared to above myths.

\section{INTERNATIONAL PRACTICES:}

The best practices deployed in advanced countries depend on:

1. Neighbourhood Education.

2. Documentation that sustains in a court of law.

3. Enforcement of legal rights of the builder.

4. Using the best Blasting Practices.

1. Neighbourhood education.

* Involves dispelling the fears about Blasting and educating them on the safe Vibration and Sound Limits.

* Documenting the defects and condition of neighbouring structures before commencement of blasting.

* Educating the community on the advantages of the project.

2. Documentation that sustains in theCourt of Law.

* Documenting conditions of the neighbouring structures by a $3^{\text {rd }}$ party who acts as a witness, in case of dispute. 
* Monitoring of Vibrations and Sound by a $3^{\text {rd }}$ party .

* Periodical Feedback and regularly attending to neighbours' concerns.

3. Enforcement of legal rights of the builder.

* Article 19 of the Constitution of India guarantees freedom to practice vocation of your choice. It guarantees livelihood.

* A false, unjustified demand can always be countered based on this Article. Where the burden of proof shifts to the petitioner, if prima facie courts can be convinced that, the Blaster has taken all the necessary precautions and could not have caused any harm.

* In the absence of prima facie evidence, as Honourable Supreme Court held in the case of M.C. Mehta v/s Union of India, the burden lies on the user of the dangerous good to prove that, the damage is not of his making.

4. Using Best Blasting Practices :

Fortunately, today technologies are available to:

* Contain the blast damage without sacrificing productivity.

* Safely use explosives

* Explosives which will blast only on a preset command.

* Fly rock and Damage Prediction Programs, etc.

\section{CONCLUSION:}

* Indian civil and mining has to excavate rock faster and safer.

* Present practices are inadequate to meet the future necessities. Our present experience is proof enough to show that our Rock Blasting Practices are inadequate even to meet our present day needs.

* Fortunately, experience of the industry in advanced countries show that there are methods to excavate rock faster and safer in huge quantities. We just need to emulate them.

\section{REFERENCES}

[1]. Electronic Detonators: Delivering The Advance In Hong Kong Ashlin Pillay, Ael Mining Services Limited Iwata Osamu, Nishimatsu Construction Company. Annual Conference Of Isee,(International Society Of Explosives Engineers) 2015, New Orleans, Usa.

[2]. Circular 7 Of 1997 Of Dgms( Director General Of Mines Safety ), Government Of India.

[3]. Blasting Related Litigation: Facts, Legal Position \& Ways Of Mitigation Methods, Srikant Vairagare And Srikanth Hariharan; $6^{\text {th }}$ Asian Mining Congress, Calcutta, February 2016

[4]. Writ Petition No.26755 Of 2007 Dated: 28-12-2007 In High Court Of Ap 